Gut, 1963, 4, 106

\title{
The serum pepsinogen level with special reference to the histology of the gastric mucosa
}

\author{
O. A. A. BOCK, G. ARAPAKIS, L. J. WITTS, AND W. C. D. RICHARDS \\ From the Nuffield Department of Clinical Medicine and the Department \\ of Morbid Anatomy, the Radcliffe Infirmary, Oxford
}

EDITORIAL SYNOPSIS Determination of the serum pepsinogen level is simple and the method gives consistent results. The serum pepsinogen level remains steady when the stomach is actively secreting pepsin. Age and sex do not greatly affect the serum pepsinogen concentration.

Serum pepsinogen levels can be correlated with the histological appearances of the gastric mucosa. The parietal cells appear to be more sensitive to injury than the chief cells. The serum pepsinogen levels of patients with pernicious anaemia are very low.

Estimation of the serum pepsinogen level is likely to prove a useful screening test for severe atrophic gastritis and gastric atrophy.

Mirsky and his associates (Mirsky, Futterman, and Kaplan, 1952; Mirsky, Futterman, Kaplan, and Broh-Kahn, 1952) studied the serum pepsinogen level. They found that it was steady throughout the day, was unaffected by diet or exercise, varied little with sex, and appeared to be constant for age after the second decade. Patients with pernicious anaemia had very low levels. Nolan (1958) and Poliner and Spiro (1958) noted that the serum pepsinogen level could be correlated with the histological appearances of the gastric mucosa, low levels being found in patients with atrophic gastritis or gastric atrophy.

Poliner and Spiro (1958) also measured the output of acid and pepsin in the gastric juice after the injection of $0.5 \mathrm{mg}$. histamine and assessed the adequacy of intrinsic factor production by one of the radioactive isotope techniques. They concluded that in general, acid fails before pepsin and pepsin before intrinsic factor, so that the stages of gastric secretory failure, although they merge one into the other, may be arranged in a natural downward progression'.

We report here our observations on the relationship between the histology of the gastric mucosa, the amount of acid secreted in response to augmented histamine stimulation, and the serum pepsinogen level.

\section{METHODS}

GASTRIC BIOPSY Gastric biopsies were performed with the flexible instrument designed by Wood, Doig, Motteram, and Hughes (1949).
The sections were stained with haematoxylin and eosin and classified into normal, superficial gastritis, atrophic gastritis, and gastric atrophy.

Superficial gastritis The lamina propria of the superficial parts of the mucosa showed increased cellular infiltration by plasma cells and lymphocytes. Neutrophil leucocytes and other inflammatory cells were observed in and around the necks of some gastric glands. The surface epithelium showed a variety of abnormalities but was not invariably abnormal. The general architecture of the glands was well preserved, there was no gross atrophy of the specific gland cells, and abundant chief and parietal cells were present.

Atrophic gastritis Inflammatory cell infiltration of the lamina propria was accompanied by atrophy of the fundic glands with a marked, although variable, reduction in the numbers of chief and parietal cells. Metaplastic intestinal glands and pyloric-type glands were sometımes present but some chief and parietal cells could always be identified. The surface epithelium was frequently abnormal.

Gastric atrophy The fundic glands showed severe atrophy with virtually complete loss of normal parietal cells and absence or marked reduction in the numbers of chief cells. Simple undifferentiated tubules, pylorictype glands, and intestinal glands were frequently present. In many instances there was little or no inflammatory cell infiltration of the lamina propria, but the presence of some inflammatory change, particularly of focal aggregates or lymphocytes, did not exclude a diagnosis of gastric atrophy provided there were virtually no specific gland cells.

AUGMENTED HISTAMINE TEST The test was performed as originally described by Kay (1953) with minor modifications (Bock, Richards, and Witts, 1963). The results 
were expressed as the total milliequivalents of acid (total $\mathrm{mEq}$. $\mathrm{HCl}$ ) secreted in one hour after augmented histamine stimulation.

SERUM PEPSINOGEN LEVEL The method used for estimating the serum pepsinogen level was a modification of that described by Edwards, Jepson, and Wood (1960). Serum was added to the substrate (dehydrated human plasma) and the acidity of the mixture adjusted to $\mathrm{pH}$ 1.5 to 2.0 . After 24 hours' incubation at $37^{\circ} \mathrm{C}$. the reaction was stopped by trichloracetic acid and the amount of 'tyrosine-like' substances in the supernatant determined by the Folin-Ciocalteau colour reaction. The density of the colour developed was compared in a Unicam photoelectric absorption meter.

The serum pepsinogen levels were expressed as units $/ \mathrm{ml}$., which represented the amount of tyrosine $(\mu \mathrm{g} . / \mathrm{ml}$.) released from $80 \mathrm{mg}$. dehydrated human plasma by the enzyme activity of $1 \mathrm{ml}$. serum in 24 hours at $37^{\circ} \mathrm{C}$. and $p \mathrm{H} 1.5$ to 2.0 .

The standard deviation of the difference between duplicate estimates of 100 samples of blood was \pm 4 units $/ \mathrm{ml}$. Dilution experiments showed that the density of the colour developed was directly proportional to the concentration of tyrosine, and when known amounts of tyrosine were added to aliquots of the substrate before incubation, it was found that the increased optical density was directly proportional to the amount of added tyrosine. The proteolytic activity of the sera appeared to remain stable when the specimens were stored at $-5^{\circ} \mathrm{C}$.

RESULTS

EFFECT OF LARGE DOSES OF HISTAMINE ON GASTRIC SECRETION OF PEPSIN AND ON SERUM PEPSINOGEN
LEVEL In 10 patients the concentrations of pepsinogen in the serum and pepsin in the gastric juice were measured during the augmented histamine test (Table I).

The concentration of the pepsin in the gastric juice rose after the injection of histamine in nine cases. The effect would have been even more marked if the concomitant increases in the volume of gastric juice secreted had also been considered. In contrast, the serum pepsinogen levels were not much altered.

SERUM PEPSINOGEN LEVEL OF 100 NORMAL PERSONS Included in this group of 100 persons were 34 nurses or members of the Nuffield Department of Clinical Medicine, 17 patients with osteoarthritis attending the Department of Physical Medicine, 29 patients over the age of 70 who were in the rehabilitation wards of the Cowley Road Hospital and who had no known alimentary diseases, and 20 friends or relatives of patients in the wards. The final group, all women between the ages of 30 and 55 , were the last subjects included in this series and they were specifically chosen to balance the sex ratio and age distribution of the population. A girl aged 17 and two men aged 92 represented the age limits of this population (mean age 49 years), 48 of whom were mon.

The serum pepsinogen levels ranged from 82 to 435 units $/ \mathrm{ml}$. with a mean of 181 units $/ \mathrm{ml}$. (standard deviation \pm 59 units $/ \mathrm{ml}$.). The mean value for men was 196 units $/ \mathrm{ml}$. (standard deviation \pm 57 units $/ \mathrm{ml}$.) and that for women was 167 units $/ \mathrm{ml}$. (standard

TABLE I

EFFECT OF AUGMENTED HISTAMINE STIMULATION ON THE CONCENTRATION OF PEPSINOGEN IN BLOOD AND OF PEPSIN IN GASTRIC JUICE ${ }^{1}$

\begin{tabular}{|c|c|c|c|c|c|c|c|}
\hline \multirow[t]{2}{*}{ Patient } & \multirow[t]{2}{*}{ Sex } & \multirow[t]{2}{*}{ Age } & \multirow[t]{2}{*}{ Biopsy } & & \multirow{2}{*}{$\begin{array}{l}\text { Before } \\
\text { Histamine } \\
\text { (units ml.) }\end{array}$} & \multicolumn{2}{|c|}{ After Histamine (units $\mathrm{ml}$.) } \\
\hline & & & & & & 30 Minutes & 60 Minutes \\
\hline W.B. & $\mathbf{M}$ & 64 & Normal & $\begin{array}{l}\text { Gastric } \\
\text { Serum }\end{array}$ & $\begin{array}{r}7,100 \\
180\end{array}$ & $\begin{array}{r}7,500 \\
150\end{array}$ & $\begin{array}{r}4,150 \\
180\end{array}$ \\
\hline G.S. & $\mathbf{F}$ & 44 & Normal & $\begin{array}{l}\text { Gastric } \\
\text { Serum }\end{array}$ & $\begin{array}{r}7,100 \\
100\end{array}$ & $\begin{array}{r}8,350 \\
90\end{array}$ & $\begin{array}{r}7,500 \\
115\end{array}$ \\
\hline M.G. & $\mathbf{F}$ & 41 & Normal & $\begin{array}{l}\text { Gastric } \\
\text { Serum }\end{array}$ & $\begin{array}{r}5,400 \\
185\end{array}$ & $\begin{array}{r}6,500 \\
180\end{array}$ & $\begin{array}{c}3,100 \\
180\end{array}$ \\
\hline M.T. & $\mathbf{F}$ & 30 & Normal & $\begin{array}{l}\text { Gastric } \\
\text { Serum }\end{array}$ & $\begin{array}{r}14,250 \\
120\end{array}$ & $\begin{array}{r}16,150 \\
130\end{array}$ & $\begin{array}{r}11,250 \\
115\end{array}$ \\
\hline P.T. & $\mathbf{M}$ & 18 & Normal & $\begin{array}{l}\text { Gastric } \\
\text { Serum }\end{array}$ & $\begin{array}{r}24,300 \\
243\end{array}$ & $\begin{array}{r}33,800 \\
255\end{array}$ & $\begin{array}{r}29,300 \\
262\end{array}$ \\
\hline T.B. & $\mathbf{M}$ & 30 & Normal & $\begin{array}{l}\text { Gastric } \\
\text { Serum }\end{array}$ & $\begin{array}{r}27,200 \\
98\end{array}$ & $\begin{array}{r}35,800 \\
90\end{array}$ & $\begin{array}{r}27,200 \\
120\end{array}$ \\
\hline G.H. & $\mathbf{F}$ & 17 & Superficial gastritis & $\begin{array}{l}\text { Gastric } \\
\text { Serum }\end{array}$ & $\begin{array}{r}2,000 \\
158\end{array}$ & $\begin{array}{r}7,100 \\
167\end{array}$ & $\begin{array}{r}5,400 \\
160\end{array}$ \\
\hline B.P. & $\mathbf{F}$ & 34 & Atrophic gastritis & $\begin{array}{l}\text { Gastric } \\
\text { Serum }\end{array}$ & $\begin{array}{r}12,750 \\
75\end{array}$ & $\begin{array}{r}16,150 \\
62\end{array}$ & $\begin{array}{r}7,900 \\
82\end{array}$ \\
\hline A.Wa. & $\mathbf{F}$ & 55 & Atrophic gastritis & $\begin{array}{l}\text { Gastric } \\
\text { Serum }\end{array}$ & $\begin{array}{r}0 \\
75\end{array}$ & $\begin{array}{r}7,100 \\
52\end{array}$ & $\begin{array}{r}5,400 \\
75\end{array}$ \\
\hline A.W. & $\mathbf{M}$ & 53 & Gastric atrophy & $\begin{array}{l}\text { Gastric } \\
\text { Serum }\end{array}$ & $\begin{array}{r}0 \\
53\end{array}$ & $\begin{array}{r}0 \\
62\end{array}$ & $\begin{array}{r}0 \\
62\end{array}$ \\
\hline
\end{tabular}

'The method for estimating the gastric pepsin concentration was the same as that for estimating the serum pepsinogen concentration, except that the aliquots were taken from samples of gastric juice which had been diluted 1 in 50 with distilled water, and the reactions were stopped after one hour's incubation. 


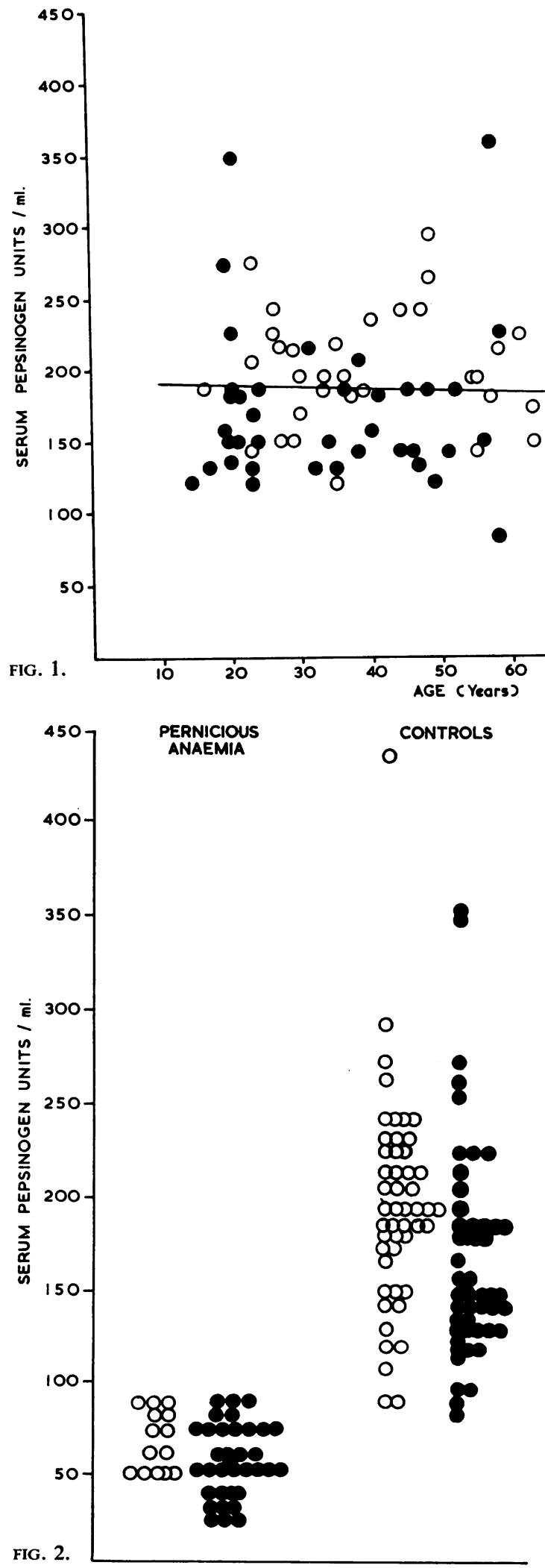

FIG. 1. A comparison of the age and serum pepsinogen levels of 100 normal persons. Open circles indicate males and closed circles females.

FIG. 2. The serum pepsinogen levels of 50 patients with pernicious anaemia compared with the levels in 100 normal persons. Open circles indicate males, closed circles females.

deviation \pm 62 units $/ \mathrm{ml}$.), a slightly significant difference $(P<0.05)$.

Age itself hardly affected the serum pepsinogen level $[(r=-0.5 ; P>0.1)(y=187-0.13 \times)]$ (Fig. 1).

SERUM PEPSINOGEN LEVELS OF 50 PATIENTS WITH PERNICIOUS ANAEMIA Serum pepsinogen estimations were carried out on 50 patients with pernicious anaemia who were attending the Anaemia Clinic. They varied in age from 47 to 88 and women outnumbered men by $3: 1$. The serum pepsinogen level ranged from 30 units to 90 units $/ \mathrm{ml}$., with a mean of 61 units $/ \mathrm{ml}$. (standard deviation \pm 19 units).

The serum pepsinogen levels of the control group are compared with the levels of the patients with pernicious anaemia in Fig. 2, and it is to be noted that there is only a small overlap in the results. The four subjects in the control population who had serum pepsinogen levels in the pernicious anaemia range were two males aged 72 and 78 and two females aged 58 and 88: all four had normal serum vitamin B12 levels, but tests for acid secretion and gastric biopsies were not performed on them.

CORRELATION OF SERUM PEPSINOGEN LEVEL WITH RESULTS OF GASTRIC BIOPSY Serum pepsinogen estimations and gastric biopsies were performed on 64 patients. These patients suffered from either iron-deficiency anaemia, pernicious anaemia. steatorrhoea, thyrotoxicosis, or diabetes mellitus. 


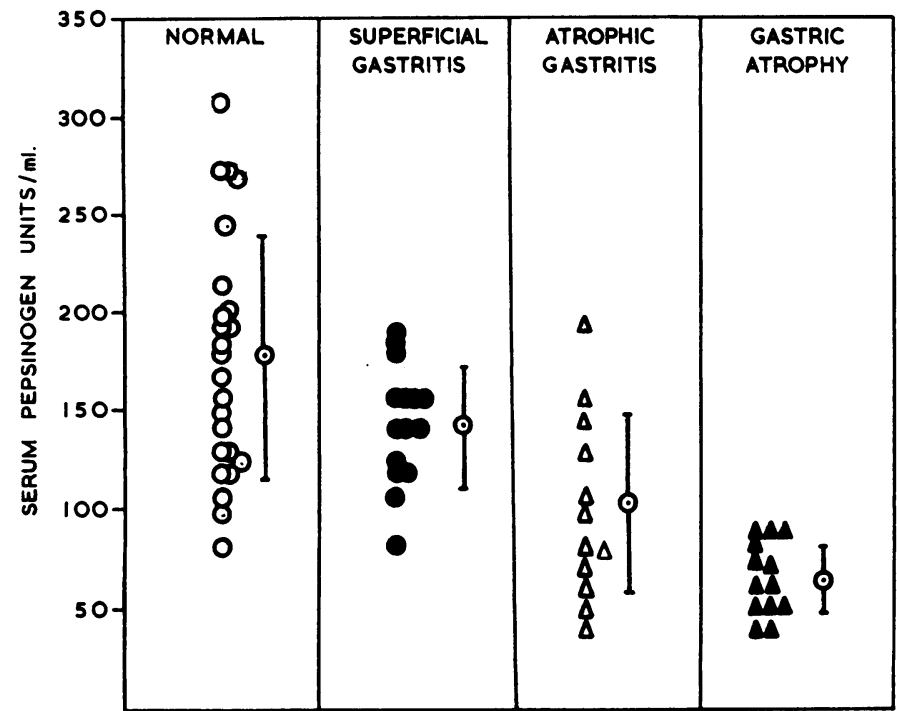

FIG. 3. The serum pepsinogen levels of 64 patients compared with the findings on gastric biopsy.
The results (Fig. 3) clearly show that the serum pepsinogen level reflects the histological appearances of the gastric mucosa. The mean value of the 24 patients with normal biopsies (178 units $/ \mathrm{ml}$.) was nearly the same as that of the 'control' population (181 units $/ \mathrm{ml}$. ), and the 13 patients with gastric atrophy had a mean value of 65 units $/ \mathrm{ml}$. which was nearly the same as that of the 50 patients with pernicious anaemia (61 units $/ \mathrm{ml}$.).
No patient with gastric atrophy had a serum pepsinogen level greater than 90 units $/ \mathrm{ml}$., which is also the upper limit in the patients with pernicious anaemia. One patient with a normal biopsy and another with superficial gastritis had levels of 82 units $/ \mathrm{ml}$.

CORRELATION BETWEEN RESULTS OF AUGMENTED HISTAMINE TESTS, SERUM PEPSINOGEN LEVELS, AND

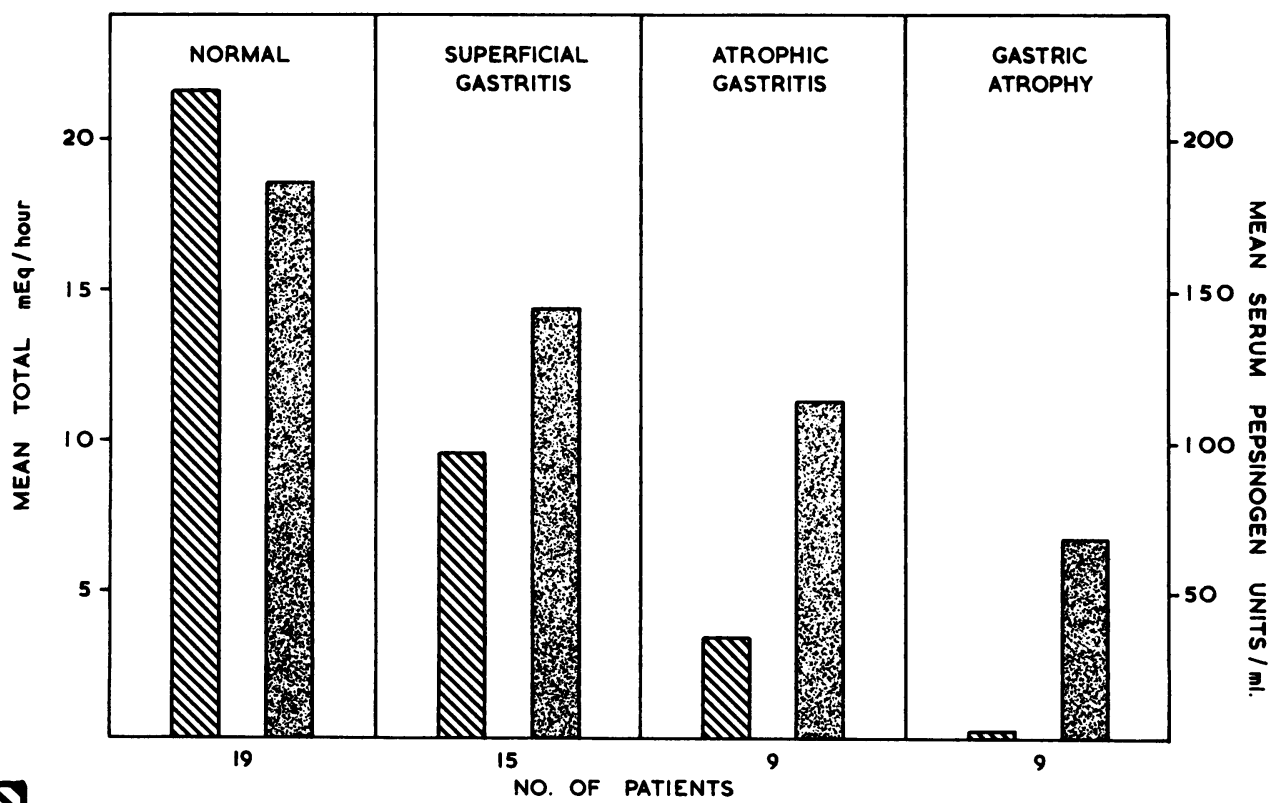

$m E q . \mathrm{HCl} /$ hour

FIG. 4. A comparison between the results of augmented histamine tests, serum pepsinogen levels, and gastric biopsies in 52 patients. 
GASTRIC BIOPSIES Augmented histamine tests were performed on 52 of the above 64 patients, and when the mean acid output and the mean serum pepsinogen level of the four histological groups are compared (Fig. 4) it is noted that the acid secretion falls off in an exponential fashion whereas the serum pepsinogen level falls more uniformly, and also less steeply.

\section{DISCUSSION}

Our results confirm the recent findings of Gillespie and Bowen (1962), who noted that large doses of histamine stimulated pepsin secretion by the human stomach: the small effect of such large doses on the serum pepsinogen level in our patients agrees with the observations of Hirschowitz (1955), who thought the level was an indirect estimate of 'the total gastric peptic cell mass or the "peptic potential" of the stomach'. We also confirm the results of Mirsky et al. (1952) and of Hoar and Browning (1956) who found that the mean value for normal women was not very different from that of normal men and that the level dropped only slightly with increasing age. In keeping with other reports (Chinn, 1953; Spiro, Ryan, and Jones, 1956; Sievers and Fischer, 1957; Nolan, 1958), our patients with pernicious anaemia had low serum pepsinogen levels.

However, our results are at variance with some of the observations of Spiro and Schwartz (1958) and Nolan (1958). Spiro and Schwartz reported that the mean level of nine patients with superficial gastritis (692 units/ml.) was above the normal range for their laboratory (200 to 450 units $/ \mathrm{ml}$.). Nolan noted that the mean of 30 patients with 'atrophic gastritis' (763 units $/ \mathrm{ml}$.) was higher than the mean of normal persons (597 units $/ \mathrm{ml}$.); because there was no difference between the mean values of patients with superficial gastritis and patients with atrophic gastritis he grouped them together as 'atrophic gastritis'.

Spiro and Schwartz (1958) were prompted to suggest that 'in superficial gastritis there is a blockage in the neck of the glands and this, together with necrobiosis of the neck cells, may lead to a regurgitation of pepsin into the blood ... ' leading to higher than normal serum levels. Nolan (1958) favoured this explanation of his results. Our observations lend no support for this view, but there is no obvious explanation for the discrepancy in the results.

The fact that the mean acid secretion appears to fall more rapidly than the mean serum pepsinogen level suggests that the parietal cells are more sensitive to damage than the chief cells, a statement first made by Riegel in 1886 and confirmed by the experiments of Ihre (1938) and by the observations of Poliner and Spiro (1958), Sievers and Gallagher
(1959), and Glass and his associates (Glass, Speer, Nieburgs, Ishimori, Jones, Baker, Schwartz, and Smith, 1960).

One explanation for this dissociation in the secretion of acid and pepsinogen would be that the parietal cells are located nearer the outlet of the gastric gland than are the chief cells and that any inflammatory process in the gastric mucosa would first impair the output of acid. It has been shown in man and animals that $x$-ray irradiation of the stomach produces prolonged achlorhydria or hypochlorhydria whereas gastric pepsin production is affected to a lesser degree and for a shorter period of time (Doig, Funder, and Weiden, 1951; Grossman, 1958). In experimental animals injury by hot water first causes a destruction of the parietal cells, with a corresponding decrease in acid secretion, and this progresses, with more intense application, to the destruction of chief cells with the loss of pepsin secretion (Grossman, 1958).

Although several groups of workers (Mirsky et al., 1952; Sievers and Fischer, 1957; Nolan, 1958; van Goidsenhoven, Wilkoff, and Kirsner, 1958; Edwards et al., 1960; Vickers and Kennedy, 1962) have shown that the estimation of the serum pepsinogen level is of little value in the differentiation between patients proven to have duodenal ulceration and those patients with suggestive symptoms in whom no ulcer could be demonstrated, our results indicate that the serum pepsinogen estimation might be a useful method for studying the prevalence of severe atrophic gastritis, gastric atrophy, pernicious anaemia, and latent pernicious anaemia. One venepuncture, to which most people would agree, would provide the blood for haemoglobin, serum pepsinogen, and serum vitamin B12 estimations. The percentage of abnormal results in normal people is small and no patient with pernicious anaemia has been found to have a serum pepsinogen concentration outside the range for histological gastric atrophy.

\section{REFERENCES}

Bock, O. A. A., Richards, W. C. D., and Witts, L. J. (1963). The relationship between acid secretion after augmented histamine stimulation and the histology of the gastric mucosa. Gut, 4 , 112-114.

Chinn, A. B. (1953). Studies on a blood proteolytic enzyme with particular reference to gastric secretory function. Gastroenterology, 25, 14-23.

Doig, R. K., Funder, J. F., and Weiden, S. (1951). Serial gastric biopsy studies in a case of duodenal ulcer treated by deep X-ray therapy. Med. J. Aust., 1, 828-830.

Edwards, K., Jepson, R. P., and Wood, K. F. (1960). Value of plasma pepsinogen estimation. Brit. med. J., 1, 30-32.

Gillespie, I. E., and Bowen, D. J. (1962). The gastric secretion of pepsin in man. Gut, 3, 255-259.

Glass, G. B. J., Speer, F. D., Nieburgs, H. E., Ishimori, A., Jones, E. L., Baker, H., Schwartz, S. A., and Smith, R. (1960). Gastric atrophy, atrophic gastritis, and gastric secretory failure. Gastroenterology, 39, 429-453. 
Grossman, M. I. (1958). In Discussions of papers presented at the 58th annual meeting of the American Gastroenterological Association. Ibid., 34, 211-212.

Hirschowitz, B. I. (1955). Pepsinogen in the blood. J. Lab. clin. Med., 46, 568-579.

Hoar, C. S. Jr., and Browning J. R. (1956). Plasma pepsinogen in peptic-ulcer disease and other gastric disorders. New Engl. $J$. Med., 255, 153-158.

Ihre, B. J. E. (1938). Human gastric secretion. Acta med. scand., suppl., 95.

Kay, A. W. (1953). Effect of large doses of histamine on gastric secretion of $\mathrm{HCl}$ : an augmented histamine test. Brit. med. J., 2, 77-80.

Mirsky, I. A., Futterman, P., and Kaplan, S. (1952). Blood plasma pepsinogen. II. The activity of the plasma from 'normal' subjects, patients with duodenal ulcer, and patients with pernicious anemia. J. Lab. clin. Med., 40, 188-199.

,,--- , and Broh-Kahn, R. H. (1952). Blood plasma pepsinogen. $\mathrm{I}$. The source, properties, and assay of the proteolytic activity of plasma at acid reactions. Ibid., 40, 17-26.

Nolan, K. E. (1958). Serum pepsinogen levels: relation to gastric secretion and gastric biopsy. Med. J. Aust., 2, 831-833.

Poliner, I. J., and Spiro, H. M. (1958). The independent secretion of acid, pepsin, and 'intrinsic factor' by the human stomach. Gastroenterology, 34, 196-209.
Riegel, F. (1886). Beiträge zur Lehre von den Störungen der Saftsecretion des Magens, $Z$. klin. Med., 11, 1-19. Beiträge zur Diagnostik und Therapie der Magenkrankheiten. Z. klin. Med., 11, 167-216. Quoted by Ihre, B. J. E., 1938.

Sievers, M. L., and Fischer, G. L. (1957). Indirect secretory studies. A comparison of tubeless gastric analysis and plasma pepsinogen determination as screening procedures. Amer. J. dig. Dis., N.S., 2, 363-376.

_ , and Gallagher, N. I. (1959). Interrelationship of acid, pepsin, and intrinsic factor production. Gastroenterology, 37, 182-187.

Spiro, H. M., Ryan, A. E., and Jones, C. M. (1956). The relation of blood pepsin to gastric secretion, with particular reference to anacidity and achylia. Ibid., 30, 563-582.

temporary achlorhydria and hyperpepsinemia. New. Engl. $J$. Med., 259, 682-684.

van Goidsenhoven, G., Wilkoff, L., and Kirsner, J. B. (1958). Serum and urine pepsinogen and gastric pepsin. Gastroenterology, 34, 421-435.

Vickers, H. E., and Kennedy, M. P. (1962). Diagnostic value of a single plasma pepsinogen estimation: an assessment in 500 cases. Brit. med. J., 1, 1453-1454.

Wood, I. J., Doig, R. K., Motteram, R., and Hughes, A. (1949). Gastric biopsy. Report on 55 biopsies using a new flexible gastric biopsy tube. Lancet, 1, 18-21. 